\title{
Reconstituting historical stratigraphy: Ugarit's Temple of Dagan
}

Tarek Teba \& Dimitris Theodossopoulos

\begin{abstract}
Purpose: The paper tests critical conservation approaches through conceptual architectural interventions that integrate the evolution of a significant urban building, the Temple of Dagan in Ugarit, the capital of an important Bronze Age civilization in Syria, with the pre-existing phases of the site and offer a paradigm for the presentation of the city's evolution. This reflection aims to investigate how far the remaining fabric can frame the original architectural experience of the place allowing the visitors of the ruins to contextualise the architectural development of the temple.

Design/methodology/approach: A detailed reading of archaeological reports and the French mission's architectural interpretation as well as in situ surveys and architectural and urban analyses were carried out to inform this conservation reflection, which primarily explores the potential of critical conservation approaches for key architectural interventions. The main vehicle is a virtual reconstruction approach to probe the proposed critical conservation principles and their success in highlighting the stratigraphy of a site.
\end{abstract}

Findings: The work shows that critical conservation approaches can make a distinct contribution to the understanding of the ruins; in particular, the virtual approach can handle effectively the presentation of the intangible experience of the temple (original processional routes) and its archaeological stratigraphy.

Research limitations/implications: The poor condition of the temple, being exposed for more than 80 years after excavation, have limited further architectural analysis as some evidence is confusing to read in situ. The pre-conservation analysis, therefore, was based more on the archaeological mission's work, which is comprehensive.

Social implications: The reconstitution of the temple's architectural layers in a coherent narrative will have educational value as it will highlight the development of architectural perception and techniques during the Bronze Age. Debate on the application of such tools by managers of the site may enhance the visitors' appreciation of the ruins. The digital output itself constitutes an engaging material that enhances the public understanding of the site and its rich stratigraphy.

Originality/value: The study is the first attempt to constitute an architectural experience out of the confusing ruins integrating the archaeological evidence in the frame of contemporary conservation and architectural design. As one of the predominant urban artefacts in Ugarit, the Temple of Dagan witnessed at least a millennium of the city's history and thus the conservation strategy of its intense development and stratification reflects the whole city. 


\section{Introduction}

Ruins are physical representations of the cultural developments of civilizations, but their discovery state does not immediately make that clear as they come to light in fragmented, confused and fragile conditions. Understanding their stratification in an architectural sense can enrich the conservation process by highlighting complex interactions in a civilization's history and cultural developments.

Religious buildings are often major representatives of cultural evolution and also monumental urban artefacts which witnessed different phases of the civilization history reflecting the cultural and ritual attitudes of ancient people as well as advancements in architectural concepts and technologies. They seem therefore ideal cases to represent evolution of human engagement in an archaeological site and this paper, therefore, developed an approach to test how far digital technologies can offer a meaningful reading and architectural experience of these sites to visitors and scholars alike.

This paper chose to test this method at the Temple of Dagan in Ugarit, the capital of an important Bronze Age civilization in Syria, highlighting its outstanding architectural, urban, social and cultural aspects as they developed over time. The Temple's ruins encapsulate a millennium of the site history but its architecture as a tower temple is unique compared to other temples of its time. As part of a broader study, the temple is also a witness how cultural and ritual aspects influenced the city's architectural and urban principles. Consequently, conservation concepts were established that such values as generators of engagement and an educational experience for the visitors. By using CAD technologies, the application of these concepts will be mapped on the ruins and their significance will be evaluated by producing photorealistic views and journeys.

\section{Context}

The City of Ugarit is a Bronze Age archaeological site, located in northwest Syria. The site is chronologically located between historic and prehistoric periods and the excavation works had revealed a very rich material culture. The most important event in Ugarit's history (the innovation of the first Alphabet and Alphabetic writing system in the 14th century $\mathrm{BC}$ ) resulted in a huge amount of records that were not only administrative archives: some scribes explain in detail Ugaritic people's social, cultural and ritual aspects (Pardée, 2000); some texts highlight people's achievements and the development of their cultural and political systems (Curtis, 1985, Yon, 2006). Excavation works carried out between 1929 and 2011, which were suspended owing to the crisis in Syria, brought to light a rich fabric that comprises royal, domestic, religious and funeral structures; in some areas, the discoveries reveal urban forms and principles too. The diverse discovered fabric in the city is a strong witness to all types of evolution the Ugaritic civilization had had between 2000 and 1185 BC; these include the development of Ugaritic people's architectural and urban experience and their attitudes towards their city and predominant structures, the temples.

The site can profit by creating very rich links between its archaeology and design, which can be based on some imposing remains and what was transmitted to us about the way its people perceived their architectural and urban spaces. The development of the city's architecture and urban landscape shows original design ideas that did not imitate forms of other surrounding cities. For example, the last development, i.e. the gate's tower and fortification show mature military planning. Also, the domestic architecture of the city indicates that builders showed careful consideration of the people's social, religious and professional aspects. Most buildings and the unique tombs in the city (Teba and 
Figure 1: (a) The location of Ugarit and its network (after Google maps). (b) Plan of the City of Ugarit showing the location of the Temples of Dagan and Baal at the Acropolis Area, in the broader context of the excavated ruins.

In addition to the brand new analysis carried out by the authors, the study is based on the archaeological reports (Courtois, 1979, Schaeffer, 1933, 1935, 1936, 1939, 1948), texts studies (Pardée, 2000,2012 ) and the latest architectural analyses done by some scholars of the French mission in Syria, such as Olivier Callot (Callot, 1985, 2008, 2013, Callot and Monchambert, 2011) and Marguerite Yon (Yon, 1991, 2000, 2006, 2009). Combining these studies made possible firstly the appreciation of the unique architectural, urban and cultural aspects of the temple. Then its analysis within the evolution of the Acropolis (Figure 1b) has shown the impact the two temples had on the city's urban and social morphology (Callot and Monchambert, 2011, p.19, 69, 84 \& 190), especially the significant evolution of religious architecture in Ugarit between the Middle and Late Bronze Age.

Critical Conservation came to being 60 years ago as a reaction to falsification or destruction occurred to heritage sites by a single interest in style, form and/or aging. The notion of this approach advocates exploring each case separately based on its physical, cultural and social settings. Therefore, it is chosen for this study to synthesise intervention approaches based on extensive analysis of the site and to consider its authenticity and integrity, but with the utmost aim to enhance the reading of its urban values and stratification by the visitors through an architectural experience. A contrast was chosen against the heaviness of the ruins by the lightness of the added materiality. Inevitably, reversibility characterises this exploration and efforts to avoid imposing a specific viewpoint of the site, while giving enough space to visitors for their own impressions.

The use of CAD modelling, to visualise the proposed approaches, has been an effective tool to generate realistic imagery of the proposed conservation procedures and explore an architectural vocabulary especially as no major restoration project has ever taken place in the site, apart from essential ruin consolidation. Computer technologies have a potential for realistic and non-destructive representations of the past, applied initially in photorealistic reconstructions of ancient sites (e.g. Pompeii, Luxor and Stonehenge) for public engagement (Barceló et al., 2000). This intention developed further and these technologies have been used to establish a rich repository of digitised surveys of the heritage environment and enhance public participation and experience (Thomas and Mintz, 1998). Consequently, visitors are not only viewers; they become learners and participants by forming their own values, actions and engagement mode (Roussou, 2002) through travel in space and time (Roussou and 
Efraimoglou, 1999). Thus, producing 3D reconstructions and journeys on heritage sites for educational and entertaining purposes has dominated the use of digital technologies, e.g. a journey through Ancient Miletus, the virtual reconstruction of the Temple of Zeus at Olympia, the Byzantine costumes and the traditional olive oil press in the Mediterranean culture (Roussou, 2002). Some organizations, the former 25th Ephorate of Byzantine Antiquities in Greece for instance, has also used these technologies to create a digital repository that facilitates easy communication with researchers and the public (Athanasoulis et al., 2015). This has been a key development stage in using CAD and digital technologies in heritage sector for research purpose.

Therefore, this paper follows this trajectory; the use of digital technology aims not only to produce a digital archive but also to test the impact of conservation approaches and architectural intervention on the ruins and their presentation. The produced materials can therefore engage visitors in the site as well as support any consultation process that would be establish to discuss the proposed architectural interventions with communities and public sectors for approvals. This ultimately meets the principles of international charters such as London Charter (Denard, 2009) and Seville Charter (Lopez-Menchero and Grande, 2011) where a great emphasis has been placed on an effective use of virtual methods and new digital technologies for better conservation, interpretation, management and dissemination of heritage cultural values.

The present paper is divided into three main parts which will introduce firstly the conservation theoretical approach, followed by the analysis of the temple and its architectural, structural and urban setting, leading eventually to the conservation reflection.

\section{Conservation Principles}

The concept of stratification first appeared in conservation through John Ruskin's "Building as a document" approach in which the respect of all historical phases was emphasised as a reaction to Viollet-le-Duc's stylistic restoration approach (Ruskin, 1849). Ruskin's approach was very suitable for artefacts as the effect of the patina of time is appreciated. Unfortunately, the literal application of this approach into historic buildings has had an unbalanced effect and has contributed to fragmentary presentation of a monument as only minimum maintenance was promoted, in blatant distinguishability that disturbs the reading of artistic and historical values. Therefore, there is a necessity for a concept beyond the "Romantic (Stylistic) Restoration" and "Building as a Document" approaches to preserve the successive and significant layers of ruins but also to facilitate a clear understanding of their interaction and cultural traits. A solution discussed here is to develop critical principles based on a combination of architectural, archaeological and historic analyses of the case, which can be expressed in contemporary design and use of materials, with respect to the fabric's authenticity.

Maximum respect to the original fabric as document and generator of the project is certainly fundamental, but an examination of the surveys and interpretations done on a monument often shows their relative value, as they have been produced in specific cultural contexts. The treatment of the monument as the utmost document is not secure then and requires survey or archive data to be studied with critical judgment and a historiographic sense (Bellini, 2005). 
As with most theories, it is important to distinguish the new additions from the existing fabric and avoid the creation of "ideal" past architectures that may have never existed. Any recreation of artistic unity is pointless though (the focus is for current societies and not the absent author) and the debate should rather be about wholeness of the work (physical rather than aesthetic form, and equally important of history and context), as C. Brandi postulated (1963). When restoration is feasible, this means that such wholeness is still accessible to the viewer, despite the fragmentation of the fabric.

Critical approaches are a meaningful way for restoration because of the realisation that any new intervention eventually adds a new layer in the monument's stratification or palimpsest (Bellini, 2005). Fragmented ruins on the other hand cannot be read as architecture or even as a stratified document, as physical loss results in a critical loss of meaning, significantly compromising both aesthetic value and cultural significance of the monument (Matero, 2005). Conservation has a dual interest in the aesthetic appearance and historical meaning of a visual work, the latter being proof of human decision (Brandi, 1963, Matero, 2007). As a consequence, a monument cannot be reduced only to a document or witness of historical or anthropological data, and recording of changes in historical meaning and cultural appreciations is not a strictly scientific task.

The authors believe that ruins have to be reconstituted as architecture and revived as a cultural act, so their restoration should be a critical act that lets them (as a work of art) indicate their intervention criteria (Bonelli, 1991). This also reduces the risk of arbitrary interpretations by the viewer, which nowadays can be tainted with political narratives or development priorities (Orbaşli, 2017). The modern science of history has also moved beyond the collection of facts towards about critical judgments and establishing connections between present and a remote past, an attitude that is typical of contemporary western societies, characterised by creative, often subjective, and critical approaches to memory (Bonelli, 1991).

In this context, the tectonic vocabulary of an intervention can be decisively contemporary. The archaeological domain has often though appeared critical to the use of modern materials in restoration (Carbonara, 2012), occasionally in ideological tones (that stem from the romantic quest for authenticity mentioned earlier) that oppose a priori to certain materials. This in addition side-lines that restoration is a design project where professionals make appropriate choices and control their application and multidisciplinarity is fundamental.

This context of critical conservation theory then and in particular the concept of the Lacuna (Matero, 2007) which was originally established to conserve works of art, are interesting to test in re-establishing the cultural values and the stratigraphy of the Temple of Dagan's ruins. A series of conceptual architectural propositions will play essential role in structuring the narrative, and the CAD technologies will enable mapping this narrative onto the ruins to evaluate the contribution of the contemporary architectural interventions to reading and understanding of the temple's history, stratigraphy and cultural values.

The Temple of Dagan was a significant building in ancient Ugarit and its architectural and historical complexity represents many of the key events in the city's development. This reflection is part of a wider range of studies in the city that include the Royal Area, the South City and the unique typology of the vaulted tombs related to the ancestors' cult (Teba, 2016, Teba and Theodossopoulos, 2014, 2015, 2016, Teba et al., 2016). The exploration of the potential of critical conservation approaches with regards to stratification can free the architectural expression to allow the reconstitution of the civic and 
private architectural experience of the temple and its evolution. The design approaches intend to render contemporary values to delicate ruins (while taking into account the reversibility and compatibility of the additions). The meeting between old and new materials/designs is a key critical act and a result of meticulous analysis, that offers design possibilities, like distinction, dialectics and reintegration of a lost image (Carbonara, 2011).

Thus, a balance between the ruins' preservation and the projection of their cultural values is explored, expected to release the embedded intangible aspects of these religious ruins. The wholeness to be restored in Dagan's Temple has to do with the meaning of the site (whose monumental presence and cultural significance have been compromised by fragmentation), its original history and contemporary values.

The reflection intervention will propose a conceptual design to expose the stratification of this building in volumetric expressions, including anastylosis works on the fragments but avoiding stylistic integrations. The proposal can ultimately facilitate the reading, the management and the use of the site. In specific, the design of cultural routes will enhance the ruins' musealisation by setting up a specific journey through the history and use of the temple focused on the ritual route and the original experience of the successive phases of the temple. This approach has been successfully applied to the Crypta Balbi museum in Rome (Crypta Balbi, 2014, Letizia-Conforto, 2014) where visitors are invited to understand the evolution of this historic site through their movement between the Roman, medieval and baroque phases. The route was designed using lightweight footpaths as well as some key reconstructions that do not affect the original ruins, but highlight the scale and architecture of some key spaces and how the City of Rome grew through decay and reconstruction.

\section{Archaeological and Architectural analysis}

The Acropolis area occupies the northeast and highest part of the City of Ugarit, approximately 4 ha in area. It accommodates the ruins of two big temples; each temple is separated with an enclosure which also comprises the temple's annexes, courtyards and external altar. The Acropolis area is not fortified similar to other acropolis areas in surrounding cultures like Hattusa in Turkey, and the name of Acropolis is just a morphological definition. The whole area is in a very fragile condition owing to more than 80 years of exposure without any real preservation work or substantial documentation, which characterised the campaigns by Claude Schaeffer 1929-1971.

The Temple of Dagan shows striking similarities to the neighbouring Temple of Baal, the main temple of the city. This was very helpful when interpreting the temple's ruins as less evidence is found there. According to Claude Schaeffer, the major archaeologist of the site, the temples were built in the late $19^{\text {th }}$ or early $18^{\text {th }}$ century BC (Schaeffer, 1935, p. 154) and were fortified but Dagan had less regularity and external spatial resolution. It was built on very thick foundations $(2.2-2.4 \mathrm{~m})$, with the northern wall being exceptional for its $4 \mathrm{~m}$ thickness (Courtois, 1979, col. 1195-1196, Schaeffer, 1935, p. 154, 1936, p. 146); Olivier Callot, an architectural scholar of the French mission, believes that this special thickness tells of special arrangements on the superstructure in that area (Callot and Monchambert, 2011, p. 7173).

Figure 2: Temple of Dagan, Ugarit, with the building bases highlighted. (a) Callot's survey of the ruins 1988-2005. (b) Foundation interpretation plan. (Callot and Monchambert, 2011, p. 166-167). 
Many scholars have been involved in the analysis of this building, such as (Courtois, 1979, Margueron, 1985, 1991, Saadé, 1979), Jean-Claude Margueron 1984 -1997 and Olivier Callot 1988-2005.

Unfortunately, this building after was uncovered in 1930s was left for more than 50 years without any substantial analysis and protection. The survey plan (Figure 2a) shows the building condition between 1990 and 2005 and its severe damage due to long exposure (Callot and Monchambert, 2011, p. 167).

\section{Architectural and Urban Settings}

The temple's enclosure (Figure 3a) encompasses the main building, two courtyards (1\&3) and a small annex (2), but many other remains disappeared due to slow degradation over time. The main building consists of two juxtaposed rectangles with less regularity of the interior spaces compared to the Temple of Baal (Callot and Monchambert, 2011, p. 136); this point has been helpful in interpreting the building's history and chronology. Callot identified three main structural elements in the building's fabric, not only the wall and its foundation but also a base. The existence of a base cannot be recognised in the Temple of Baal, and that points out the first, and crucial, difference between the two temples.

There is no evidence of the building's entrance, so based on Schaeffer's excavation reports (Schaeffer, $1933,1935,1936,1939,1948)$ and his 1990 s survey plans, O. Callot proposed an identical entrance system to the one at the Temple of Baal, drawing on additional similarities between the two temples: a porch made of two antes and two timber columns between them (Figure 3a: 7). In the South Hall of the temple, the bases do not follow the building foundations and walls (Figure 2a\&b), but they are irregular, creating a trapezoidal shape. It is believed that this did visually affect the building's character and architectural appearance during the city's life, as these bases were totally covered under the building's foundations. This irregularity raised a substantial question as to whether these bases were related to another older structure before the temple's construction in $19^{\text {th }}$ century BC (Callot and Monchambert, 2011, p. 69-72).

The South Hall, a simple probably public vestibule, gives access to the North Hall, the Most Holy Place, which consists of the altar complex in the ground floor and other holy levels upwards. The North Hall has almost identical plan to the Temple of Baal's, but It is just the intermediate space that is missing (Callot and Monchambert, 2011, Teba et al., 2016). This inspired Callot to hypothesise a door between the two spaces (Figure 3a:4\&5), south and north halls. The sounding analysis in the building by Callot in 2005 has shown that the foundations of the South Hall and the altar structure are shallower than those of the North Hall (Callot and Monchambert, 2011), indicating that the latter consisted of two stories or more. Since the altar's walls did not continue to the first floor and considering the thickness of the northern wall $(4 \mathrm{~m})$, Callot believes that the second flight of the staircase that led to the temple summit, built on top of this part of the building, was embedded in the upper part of the northern wall. Compared to the other three foundations, this wall is much thicker and can be entrusted for structural purposes, being located at the beginning of the slope of the hill towards the Lower City. However, it does not make sense that the same thickness continues to the first floor which eventually supports Callot's interpretation.

Proposing another structure, the temple's summit, over the northern wall is merely hypothetical and, apart from the thick foundation, no physical evidence can support it further. However, the striking similarity of this temple to the Temple of Baal but with a thicker foundation inspired Callot to reach this conclusion. It is believed that the North Hall consisted of three holy levels, the balcony with the roof of the vestibule, the roof of the Hall and the temple's summit on top of the northern wall (Figure 3b) 
(Callot and Monchambert, 2011, Margueron, 1985, Yon, 1984). This vertical hierarchy of sacred spaces highlights the beliefs and ritual practices of the city, which will be explored in better detail in later section of this analysis.

Figure 3: (a) Plan of the Temple of Dagan: after the topographic survey and the architectural analysis (author). (b) Section in the temple by (Callot and Monchambert, 2011).

In addition to the main body, the enclosure comprises of two courtyards. In front of the building, a narrow courtyard existed; however, it is difficult to propose that it accommodated any outside activities. It is believed that the building originally had no fortified enclosure, but the urban development of the area defined the temple's borders afterwards (Callot and Monchambert, 2011, p. 73, Margueron, 1977). To the southeast, another spacious courtyard can be recognised. Its location highlights the second conceptual difference to the Temple of Baal (Teba et al., 2016) whose main courtyard are located in front of the main entrance. Some stone troughs were discovered there in a disordered arrangement, adjacent with the foundations of a light structure, an altar perhaps (Margueron, 1991, 2003). The archaeological level of these troughs confirms they were not corresponding to the temple's phase (Courtois, 1979, Margueron, 1991, Saadé, 1979, Yon, 1991). The ruins of the small annex in the southwest corner show that this temple had secondary access through the annex (Figure 3a:2). The main entrance does not exist anymore; however, Callot proposes that it was designed similarly to the Temple of Baal's, i.e. two large stone jambs and wide opening (Callot and Monchambert, 2011). These relationships that the Temple had with the surrounding fabric and the city reflect its importance to everyday life and embody part of the experience people had inside and outside the temple. Although these spaces were simpler but less regular compared to the main temple of the city, the Temple of Dagan with the excavated remains outside and below the building present very interesting stratifications which confirm the long history of habitation at the site, dating back to before $19^{\text {th }}$ century $\mathrm{BC}$, the expected date of the Temple construction.

\section{Construction techniques and architectural planning experience}

Physical evidence confirms that the builders considered the building's geometry from the beginning of the construction process. The differences in width (Figure 2) and depth (Callot and Monchambert, 2011, p. 168-170) of foundations align with the difference in geometry between the temple's north and south halls; this points out to Ugaritic people's professionality and planning experience as early as in the $19^{\text {th }}$ century BC. The builders successfully considered the geographical settings of the area and perfectly adapted the foundations to make the slope accommodate the massive structure, especially the northern wall, the highest part of the building (Castel, 2001). The thickness of this wall, built in high quality cut stones, was a proper solution for this critical point (Figure 4a), as was the foundation of the southern wall of the North Hall (Figure 4b), which was capable to receive loads from the structure of the two, south and north, halls. This further adapted the building on the slope with aesthetic solutions as parts of these foundations were exposed due to the slope (Figure $4 b$ ). 
A new structure was added to the western wall of the North Hall, the so-called "glaze" which was built as an inclined wall doubling the western wall of the Most Holy Place (Figure 3:8, 5a). This element does not belong to the original structure from $19^{\text {th }}$ century BC; an investigation was carried out by Callot in May 2005 (Callot and Monchambert, 2011, p. 83-86) which confirmed that the foundations of this glaze are shallower and totally separated from the original foundations of the temple. These discoveries pointed out that the temple stayed in use after the earthquake of $1250 \mathrm{BC}$, an event that affected the whole city; since less artefacts were found compared to the Temple of Baal, it seems the Temple of Dagan maintained its sacred function but was heavily damaged and was transformed to an open-air platform. The new glaze would have been added for aesthetic reasons, to give a particular form to the new sacred podium, the platform-temple. It is not confirmed yet, however, whether this glaze had any structural function to support the remains of the western wall of the North Hall after the earthquake.

Consequently, the temple had interesting geometries that represent the architecture of that time for such important buildings. The cultural attributes of the sophisticated consideration of the structural and aesthetic qualities of the temple cannot be clearly communicated to the visitors using the ruins only and therefore it is necessary to test architectural approaches to expose and map these attributes onto the temple's original ruins.

\section{$\underline{\text { History and Chronology Discussion }}$}

The soundings carried out inside the temple (Callot and Monchambert, 2011) revealed materials and foundations that date back to the very beginning of the Middle Bronze Age. This area consequently exhibits a very interesting stratigraphy which encouraged the archaeologists to believe that this was the start point of the city in the $20^{\text {th }}$ century BC. Also, archaeological surveys and soundings, conducted by Schaeffer in the Temple of Dagan (Schaeffer, 1935, 1939), brought to light another (Early Bronze Age or Middle Bronze Age II) layer of compacted white soil which dates back to before the construction date of the temple (Callot and Monchambert, 2011, p. 79). The presence of the stone troughs (Figure 5b), which are not related to a similar phase of the temple, in the southeast courtyard further confirms the existence of other cultic facilities before the construction of the temple in $19^{\text {th }}$ century BC. J-C Courtois had assigned those troughs to a libation and ablution function (Courtois, 1979, col. 1196). However, Marguerite Yon proposed that these blocks would have functioned as bases for stelae which served outdoors rituals during the Early Bronze Age and the beginning of Middle Bronze Age periods (Dunand, 1958, Yon, 1991, p. 293-280). Yon established a comparison with similar troughs existing in the Temple of Resheph (the Temple Obelisks) in Byblos, Lebanon to support her interpretation.

Figure 5: (a) Stone troughs found in the southeast courtyard of the Temple of Dagan. (b) The glaze added to the western wall of the Temple of Dagan.(Callot and Monchambert, 2011)

Parts of the foundations of the quadrangular wall enclosure, which surrounds these troughs, are still preserved (Margueron, 2003, p. 311, Yon, 1991, p. 293-280) giving the impression that the troughs agglomeration served as an altar or a place for outdoors cult. The temple's bases show evidence for the existence of another structure before the temple was built. Keeping the foundations of earlier buildings to use them in later structures is a strong assumption, in line with practice during the Bronze Age period, like in the Temple of Kition in Cyprus (Yon, 2009). In line with these interpretations, Yon believes that the troughs complex, the white compact soil and the earlier bases constituted the Middle Bronze Age 
Temple of Dagan (Yon, 1991, p. 293-280). This further confirms earlier conclusion in this paper regarding the interesting stratigraphy of and the long history of habitation in the site of the temple and as a result in the City of Ugarit, a historic value of this city that needs to be highlighted by appropriate physical evidence.

$\underline{\text { Ugaritic rituals and the architecture of the temples }}$

Ugarit was part of the Canaanites religions and one of their beliefs was that their gods existed in a very sacred and untouched environment. Therefore, the king's sacrificing cults in the temples required approaching high and sacred parts of the building by keeping human intervention to a minimum: only the king and the priest were allowed to approach such places. This was confirmed in the ritual text found in the House of the High Priest "The Legend of Keret" (Pardée, 2000, 2012) which describes one of the sacrificing cults that the king used to carry out in the main temples, in its highest and most sacred place.

Reviewing the structure of the Temple of Dagan and the Temple of Baal (Callot and Monchambert, 2011, Teba et al., 2016), it is clear that this belief strongly influenced the temples' architectural principles and the way their superstructures was arranged at the Acropolis. Ugaritic people, in a manner different from other surrounding cultures, constructed their temples to adapt specifically to the rituals of their beliefs, so these temples had a new form, the tower-temple type (Margueron, 1991, p.15-31, Margueron and Boutte, 1995), which allowed easy and sufficient practice of the cult. Fulfilling the practice requirement became a priority for Ugaritic people and as a result the temples had been freed from following the cardinal directions, which was strictly followed by the surrounding cultures; these temples were also shaped based on the required function. The analysis of Ugaritic tombs (Teba and Theodossopoulos, 2015) also confirms the fact that Ugaritic people prioritised better performance in their structures and invented new architectural rules to fulfil their religious, cultural and functional attitudes rather than merely following inherited principles and rules that were popular in the area.

The ritual aspects (e.g. seeking the most sacred spaces for practicing the rituals) also affected the arrangement of the sacred spaces in the temples' ground floor. Although the whole temple was considered to be a sacred building, its spaces were constructed in gradual sacredness from the open courtyard outside to the deepest point of the temples, the internal altar section. This concept of gradual privacy became a dominant principle in Ugaritic architecture. As a result, it is clear that both the geometry and the spatial arrangements of the Temple contribute to reflecting the cultural attributes associated with this building ruins; these intangible values need to be manifested using a contemporary architectural and conservation approach but benefiting from the original spatial quality of the ruins.

\section{Cultural Values of the Temple of Dagan}

In summary, the values of this symbolic temple are as follows:

1. The gigantic volume as well as the planned design of the Temple have a twofold cultural value: they reflect the significance of this building for the understanding of the city's urban form and people's cultural aspects; this enriches the knowledge of local communities and visitors about this era of the site's history. These characteristics also shed the light on the design creativity, planning skills as well as the construction and building experience that Ugaritic people had in the past; that constitutes valuable cultural and educational aspect which is of an interest for local people as part of their extended history and their ancestors' achievements. 
2. The interesting stratigraphy along three stages of the site's history enriches the current interpretations and values of the site and people understanding of these stages in relation to the well-known civilizations of the time. Understanding this stratigraphy and the development of the temple throughout the history of the site contributes to the current knowledge about the history of the area as well as the religious building of the region.

3. The temple faithfully represents the rituals and beliefs of Ugaritic people either by its arrangement or by the hierarchy of sacred spaces. The link between religion, culture and architecture is not evident in many historic sites and therefore it is interesting aspect that adds to the site's interpretation and values.

\section{Conservation Proposal}

As mentioned earlier, this paper adopts critical conservation concepts that are based upon careful archaeological and architectural analyses, and subsequently the virtual reconstruction approach is an effective tool to probe the value of proposed interventions, to reconstitute the temple's analysis and stratigraphy, and to revitalise its cultural significance. The virtual experience of the site is explored, mapping cultural values onto the original ruins using design concepts and testing several hypotheses. Considering the fragile condition of the ruins, the proposal also considers the optimal ways to explore the site causing no further damage by the visitors. Using CAD software, a simple virtual model of the ruins of the temple and part of its surrounding was built based on information derived from the archaeological and architectural reports as well as the site visit conducted in 2013 . The materiality of the original ruins was used in the virtual model to achieve a better realistic model of the ruins. Then, the proposed critical conservation approaches and conceptual architectural interventions were erected over the model using the new proposed materiality in order to allow for fair and sensitive appreciation of how new designs and materials affect the overall perception of the ruins. Using ArchiCAD, a CAD software, photorealistic renderings as well as videos that simulate the proposed visitors journey and experience within the ruins before and after the interventions were produced to evaluate the legibility of proposed intervention in enhancing the perception of the identified cultural values of the Temple.

Since the proposal was built upon the visitors' experience within the original context, the proposal include installing a musealisation route to guide the visitors, following the development of the temple's architecture from Early Bronze Age (perhaps, the beginning of the Middle Bronze Age). The route will start with gate of the Middle Bronze Age enclosure which highlights the first direct connection with its assigned street. Then, the route will head east towards the southeast courtyard where the first layer of this building existed and subsequently will wind around the quadrilateral shape foundations which flanked the troughs agglomerations (Figure 6:3, 7a).

The proposal will consider that this area functioned as an outside altar which had stelae fixed on the troughs, like the Temple Obelisks in Byblos, Lebanon (Dunand, 1958, Yon, 1991). These foundations are not found complete in place; therefore, their missing parts will be completed to produce the expected footprint of this outdoor facility, using reversible and recognised materials (Figure 7a) like rammed earth to enable differentiation from the original parts and to indicate the hypothetical nature of this reconstruction. The troughs will be tidied up and other dispersed troughs will be returned into their 
original agglomeration within the quadrilateral shape area. The conservation proposal will emphasise them as bases for stelae whose replicas will be installed, with reference to the Temple Obelisks in Byblos (Figure 7a). Stones are the main building materials in Ugarit, so the use of rammed earth, that resists the weather conditions, will provide sufficient differentiation for the installed interventions.

Figure 6: Detailed plan for the conservation proposal of the Temple of Dagan.

Thereafter, the route will lead to the main building of the temple where other two stratifications exist, the before and after-earthquake $1250 \mathrm{BC}$ phases. The former is represented by the $19^{\text {th }}$ century BC remains, while the latter (The open podium temple) was obliterated by the excavation works. It is believed that, after the earthquake, the ruins were covered with compact soil to create the new open podium whereas the altar, where the deity statue or stele was placed in all likelihood in the same place. The excavation work brought to light less artefacts compared to the Temple of Baal, but discovering the Dagan's stele indicates that the building was still in use during the last days of the city's life, though in a podium form.

As a result, the proposal will focus on two important aspects: the overlapping between the two phases as well as the gigantic volume of the first phase of the temple. The reconstruction of the original footprint of the $19^{\text {th }}$ century BC temple will be carried out with partial anastylosis, re-locating the original stones available on the specific walls to avoid any falsification. The stones will be rebuilt using traditional lime and soil mortar. Then, the original level of the second phase platform will be reconstructed with a steel mesh that enables the musealisation and protection of the ruins underneath. It is a design choice for the steel mesh to have irregular pattern to avoid making any reference and serve as the backing of the lacuna; the mesh is detailed to complete the walls and to meet the inclination of the glaze (Figure $7 b$ ), but raised using intermediate supports that are located in empty spaces inside the temple to eliminate any interaction with the original fabric. Furthermore, these supports should not in any way confuse the reading of the original ruins beneath the mesh. The same principle was employed and transparent glazing was used to complete the volume of the Temple of Augusto, Pozzuoli but maintaining the contemporary relationship between the ruins and the surrounding historic context and avoiding stylistic completions.

The altar place will be highlighted on the mesh by installing a replica of the stele of Dagan in the same vertical position as the original one (Figure $7 \mathrm{~b}$ ). Since this temple reconstruction is schematic, some architectural features like the staircases that guided to other levels of the Most Holy Place above, will be highlighted on the steel mesh using regular frames to present their footprint (Figure $7 \mathrm{~b}$ ). This will give the visitors a glimpse of the arrangement of the first phase of the building, of which very little evidence exists, but its interpretation was mostly based on the striking similarities with the Temple of Baal. For that, the arrangement in the Temple of Dagan will be rather conceptual to highlight the uncertainties in the available archaeological evidence.

Figure 7: (a) Virtual conservation exploration for the southeast courtyard. (b) Virtual representation of the installed mesh on the temple's ruins, highlighting specific arrangements of the first phase. 
The installed route will continue over the ruins at the same level as the steel mesh to facilitate the musealisation of the ruins of the first phase, and create for the visitors an architectural experience of the last phase of this temple. For that purpose, three timber platforms will be formed to highlight the vestibule area as well as the altar platform inside the Most Holy Place (Figure 6\&8). The route and its platforms will be made of oak which is closely related to the site and its history.

A timber staircase will be installed to let people go up to the level of the installed steel mesh, starting with the ruins of the South Hall, the vestibule. Unfortunately, there is no evidence that would confirm how people approached the last phase platform. Therefore, the staircase will be installed as an integral part of the overall musealisation route, but the landing at the level of the mesh will be at the midpoint of the entrance wall to preserve the symmetric perception of the temple's first phase access (Figure 8).

Figure 8: Virtual conservation exploration for the Temple of Dagan.

The route on the mesh will be flanked with steel and glass balustrade for visitors' protection. The way downwards will be through another staircase which will guide the visitors to the temple's annex whose footprint will be restored using the original stones (Figure 8). Through this annex, the proposed route will highlight the other exit of the temple's enclosure guiding visitors to the indirect link between the temple's complex and its assigned street.

As to the gigantic volume of this temple, it has a high urban, architectural and constructional significance that must be highlighted. As seen in the analysis, this building had provided less evidence and the primary contribution of its conservation proposal is to show its stratigraphy. Therefore, to avoid overwhelming the exposed stratifications, the reflection of this building's volume will be light and conceptual, using a subtle framed steel structure to show the overall massive volume without specific details (Figure 8); this framed structure will have no envelop so it will conceptually recall the original volume of the temple. The supports of the framed steel structure will be installed outside the temple borders to avoid causing damage to the original foundations. This approach successfully reflected the volume of some architectural elements in the Roman ruins of Can Tacó (Aravena, 2013) and lesso in Spain. This concept helps to maintain the visitors' concentration on the building stratigraphy and enhance their perception of the final state of this temple which does not involve its gigantic volume.

\section{Conclusion}

Archaeological analysis has shown that religious buildings in Ugarit are strong representations of cultural and architectural developments. The ruins of the Temple of Dagan, which was hidden for more than 3000 years, hold authentic evidence of Ugaritic people religion, life style, experience, skills, approaches, etc. These ruins represent the high level of architectural, planning and technical experience of Ugaritic people during the Middle Bronze Age. The development of this gigantic structure also reflects different attitudes during Middle and Late Bronze Age, especially after the major earthquake of 1260 BC.

The conservation proposal of the Temple of Dagan highlights its evolution and associated social and cultural aspects. The use of critical conservation approaches and conceptual designs enabled the presentation of the buildings' stratigraphy and developments in coherent musealisation approaches, which will be of a high educational value for academic and public visitors. The proposal has responded to specific knowledge of the history, condition, clarity and stratifications of the ruins, and expressed the 
associated cultural values and aspirations of the temple's ruins in their cultural and spatial settings; it enables to appreciate the evolutionary steps that promoted the architecture of Ugarit between Early, Middle and Late Bronze Age. The restoration of the Acropolis main temples (Teba et al., 2016), as key urban artefacts in the city, can eventually play a primary role in the overall reading and appreciation of the city's urban principles and structure and set the tone for similar interpretations in other areas.

By using CAD programs, commonly-used and widely available, the virtual reconstruction approach has been effectively used to test different proposals and the implications of some interventions on the original ruins, which has subsequently enhanced the decision-making. By analysing the produced renderings and videos, the proposed conservation approaches, interventions and materials were evaluated and amended where they confused the ruins and their perception, until the final renderings indicated legible proposals. Produced photorealistic images and videos constitute rich materials that can facilitate further critical discussion around these interventions as well as the employed conservation approach and process. They can be also potentially used for the consultation and feedback stages before proceeding to the final detailed designs for the proposed interventions for the Temple, if it is deemed necessary to physically build these interventions in the future.

\section{Bibliography}

Aravena, A. 2013. Adecuación del Yacimiento Romano de Can Tacó [Online]. Available: https://goo.gl/L9Y7Qk [Accessed 10 February 2015].

Athanasoulis, D., Georgiou, A., Simou, X., Sfika, A., Klotsa, V., Zirogianni, T., Theodoropoulos, C. \& Deligianni, E.-O. Bridging monuments through digital repository and graphic reconstruction methodologies the Digital Enhancement project of Argolid, Arcadia and Corinthia castles, Greece. 2015 Digital Heritage, 2015. IEEE, 107-110.

Barceló, J. A., Forte, M. \& Sanders, D. H. 2000. Virtual reality in archaeology, Oxford ArcheoPress. Bellini, A. 2005. Che cos'è il restauro. Nove studiosi a confronto. In: Torsello, B. P. (ed.). Marsilio. Bonelli, R. 1991. Restauro: I'immagine architettonica fra teoria e prassi. Storia architettura, 11, 5-14. Brandi, C. 1963. Teoria del restauro, Ed. di storia e letteratura.

Callot, O. 1985. Remarques sur l'Architecture des Temples 1 et 2. In: Karageorghis, V. \& Demas, M. (eds.) Excavations at Kition V: The Pre-Phoenician Levels. Nicosia: P. 165-239.

Callot, O. 2008. Réflexions sur Ougarit après ca 1180 ap. J.-C. . In: Calvet, Y. \& Yon, M. (eds.) Ougarit au Bronze moyen et au Bronze récent: actes du Colloque international tenu à Lyon en novembre 2001," Ougarit au lle millénaire av. J.-C., état de recherches". Lyon, France: Maison Orient Mediterraneen.

Callot, O. 2013. réflexions sur le palais nord d'Ougarit. Syria. Paris.

Callot, O. \& Monchambert, J.-Y. 2011. Les sanctuaires de l'acropole d'Ougarit: les temples de Baal et de Dagan, Publ. de la Maison de l'Orient et de la Méditerranée.

Carbonara, G. 2011. Architettura d'oggi e restauro: un confronto antico-nuovo, UTET scienze tecniche.

Carbonara, G. 2012. An Italian contribution to architectural restoration. Frontiers of Architectural Research, 1, 2-9.

Castel, C. 2001. Naissance et développement d'une maison dans la «Ville Basse» orientale d'Ougarit (fouille 1936). Ras Shamra-Ougarit XIV: Études ougaritiques I, Travaux 1985-1995, 41-64.

Courtois, J.-C. 1979. Ras Shamra. I. Archéologie. Supplement au dictionnaire de la Bible Paris, 9, 12251295. 
Crypta Balbi. 2014. Museo Nazionale Romano Crypta Balbi: Progetto di Scavo, Restauro Conservativo e Allestimento [Online]. Available: http://goo.gl/3RmY0O [Accessed 20 August 2014].

Curtis, A. 1985. Ugarit (Ras Shamra), Cambridge, Lutterworth.

Denard, H. 2009. The London Charter for the computer-based visualisation of cultural heritage. London: http://www.londoncharter.org.

Dunand, M. 1958. Fouilles de Byblos II, 1933-1938. Atlas et Texte.

Letizia-Conforto, M. 2014. RE: Museo Nazionale Romano - Crypta Balbi 1981 -2011: The Leson of History.

Lopez-Menchero, V. M. \& Grande, A. The principles of the Seville charter. CIPA symposium proceedings, 2011. 2-6.

Malbran-Labat, F. 1999. Commerce à Ougarit. Le Monde de la Bible.

Malbran-Labat, F. 2000. Commerce at Ugarit. Near Eastern Archaeology, 63, 195-195.

Margueron, J.-C. 1977. Ras Shamra 1975 et 1976 Rapport préliminaire sur les campagnes d'automne. Syria, 151-188.

Margueron, J.-C. 1985. A propos des temples de Syrie du Nord. Sanctuaires et clerges, Strasbourg, citato nel.

Margueron, J.-C. 1991. Sanctuaires sémitiques. Supplément au Dictionnaire de la Bible, 11, 1104-1257.

Margueron, J.-C. 2003. Les mésopotamiens, Editions A\&J Picard.

Margueron, J.-C. \& Boutte, V. 1995. Emar, capital of Aštata in the fourteenth century BCE. The Biblical Archaeologist, 58, 126-138.

Matero, F. 2005. Predicting the past: Situating history within Rome's Orto Botanico. Studies in the History of Gardens \& Designed Landscapes, 25, 87-102.

Matero, F. G. 2007. Loss, compensation, and authenticity: the contribution of Cesare Brandi to architectural conservation in America.

Orbaşli, A. 2017. Conservation theory in the twenty-first century: slow evolution or a paradigm shift? Journal of Architectural Conservation, 23, 157-170.

Pardée, D. 2000. Les textes rituels, Éditions Recherche sur les civilisations.

Pardée, D. 2012. The Ugaritic texts and the origins of West-Semitic literary composition, Oxford University Press.

Roussou, M. 2002. Virtual heritage: from the research lab to the broad public. BAR International Series, 1075, 93-100.

Roussou, M. \& Efraimoglou, D. High-end interactive media in the museum. PSIGGRAPH'99 26th International Conference on Computer Graphics and Interactive Techniques, 1999 Los Angeles, CA, USA. 59-62.

Ruskin, J. 1849. The seven lamp of architecture, the lamp of memory. John Ruskin: selected writings, 1627.

Saadé, G. 1979. Ougarit, metropole cananeenne, Beyrouth, Liban, Impr. Catholique.

Schaeffer, C. F.-A. 1933. Les fouilles de Minet-el-Beida et de Ras-Shamra: Quatrième campagne (printemps 1932). Rapport sommaire. Syria, 93-127.

Schaeffer, C. F.-A. 1935. Les fouilles de Ras Shamra-Ugarit. Sixième campagne (printemps 1934). Rapport Sommaire. Syria, 141-176.

Schaeffer, C. F.-A. 1936. Les Fouilles de Ras Shamra-Ugarit. Septième campagne (printemps 1935) Rapport sommaire. Syria, 105-149.

Schaeffer, C. F.-A. 1939. Ugaritica, Paris, P. Guethner.

Schaeffer, C. F.-A. 1948. Stratigraphie comparée et chronologie de l'Asie occidentale, llle et lle millénaires: Syrie, Palestine, Asie mineure, Chypre, Perse et Caucase, Cumberlege.

Teba, T. 2016. The conservation of archaeological sites in Syria: Ugarit as a case study. University of Edinburgh. 
Teba, T. \& Theodossopoulos, D. Connecting between phases: the conservation of the Royal zone in Ugarit. REHAB 2014: International Conference on Preservation, Maintenance and Rehabilitation of Historical Buildings and Structures, 2014. Green Lines Institute for Sustainable Development.

Teba, T. \& Theodossopoulos, D. Keeping the fathers alive: the conservation of funeral architecture in Ugarit. In: Amoeda, R., Lira, S. \& Pinheiro, C., eds. REHAB 2015: 2nd International Conference on Preservation, Maintenance and Rehabilitation of Historical Buildings and Structures, 2015. Green Lines Institute for Sustainable Development.

Teba, T. \& Theodossopoulos, D. A graphic reconstruction methodology for the conservation of cultural heritage. ASCAAD 2016: The 8th International Conference of the Arab Society for Computer Aided Architectural Design.: Parametricism Vs. Materialism: Evolution of digital technologies for development, 2016. Imperial House Publishers.

Teba, T., Theodossopoulos, D. \& Crow, J. Exposing the sacred monumentality in Ugarit: remodelling the Temple of Baal. In: Van Balen, K. \& Verstrynge, E., eds. 10th International Conference on Structural Analysis of Historical Constructions: SAHC 2016, 2016. CRC Press Inc.

Thomas, S. \& Mintz, A. 1998. Virtual and the Real: Media in the Museum, American Association of Museums.

Yon, M. 1984. Sanctuaires d'Ougarit in Temples et sanctuaires. Travaux (Les) de la Maison de l'Orient Lyon, 37-50.

Yon, M. 1991. Stéles de pierre. Ras Shamra-Ougarit VI, 271-344.

Yon, M. 2000. A trading city: Ugarit and the west. Near Eastern Archaeology, 64, 192-193.

Yon, M. 2006. The City of Ugarit at Tell Ras Shamra, Eisenbrauns.

Yon, M. Cities of the Levant: Ugarit and Cyprus. Bronze Age Architectural Traditions in the Eastern Mediterranean: Diffusion and Diversity: proceedings of the symposium, 07-08.05. 20082009 Munich/Gasteig München. erein zur Förderung der Aufarbeitung der Hellenischen Geschichte, 153-170. 

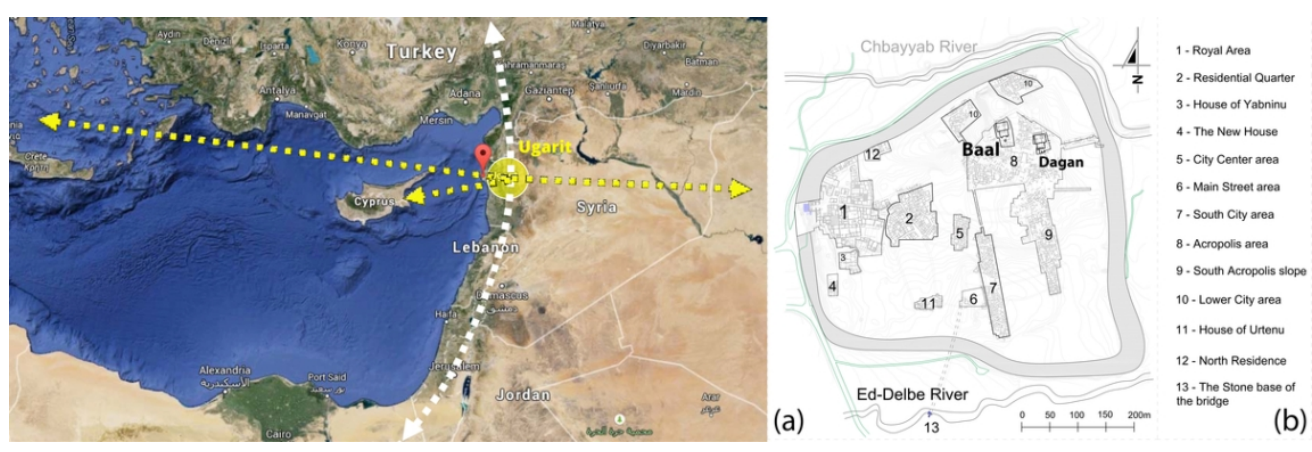

(a) The location of Ugarit and its network (after Google maps). (b) Plan of the City of Ugarit showing the location of the Temples of Dagan and Baal at the Acropolis Area, in the broader context of the excavated ruins.

$203 \times 66 \mathrm{~mm}(150 \times 150 \mathrm{DPI})$ 


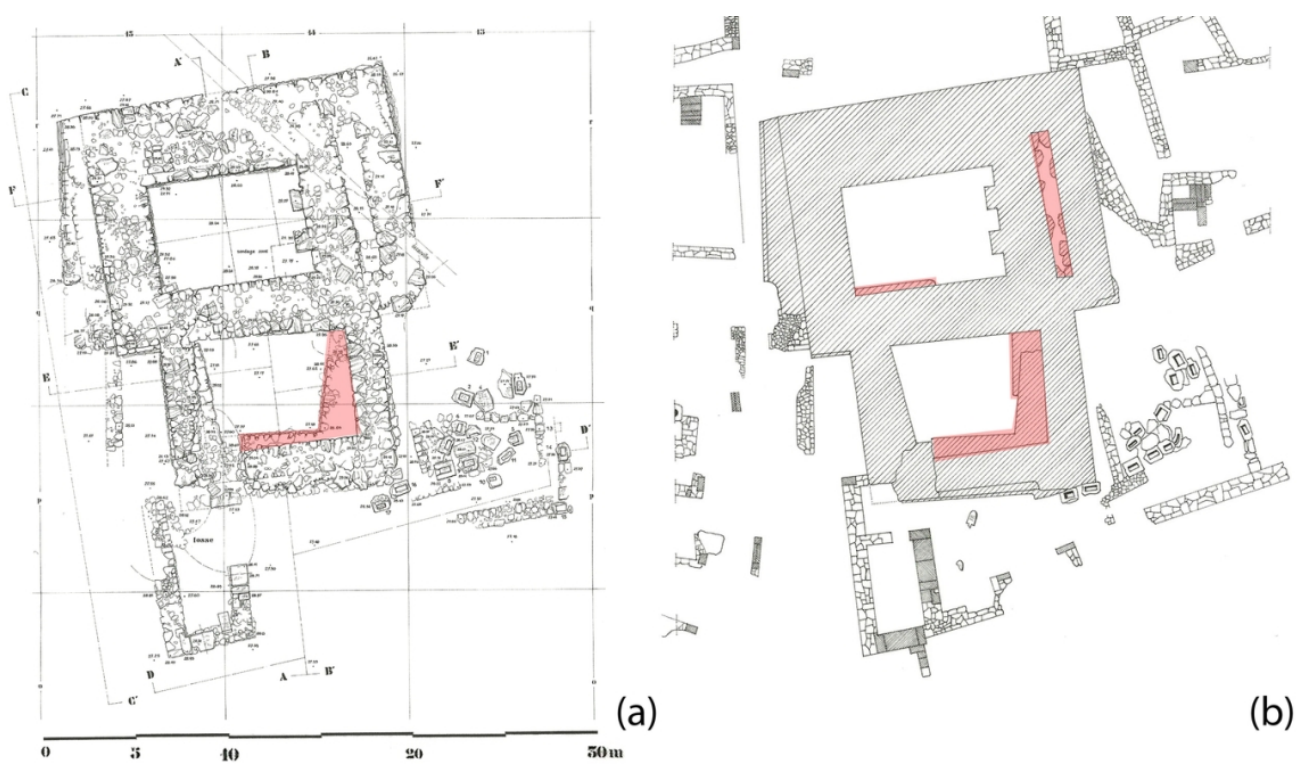

Figure 2: Temple of Dagan, Ugarit, with the building bases highlighted. (a) Callot's survey of the ruins 1988-2005. (b) Foundation interpretation plan. (Callot and Monchambert, 2011, p. 166-167).

$229 \times 131 \mathrm{~mm}(150 \times 150 \mathrm{DPI})$ 


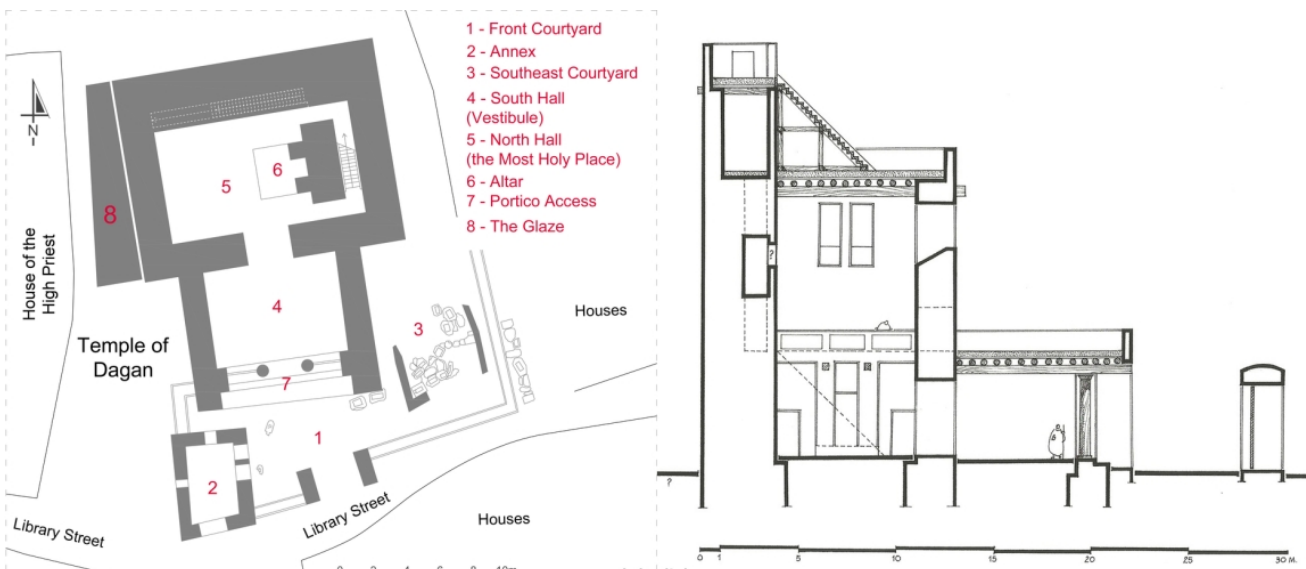

(a) (b)

(a) Plan of the Temple of Dagan: after the topographic survey and the architectural analysis (author). (b) Section in the temple by (Callot and Monchambert, 2011). 

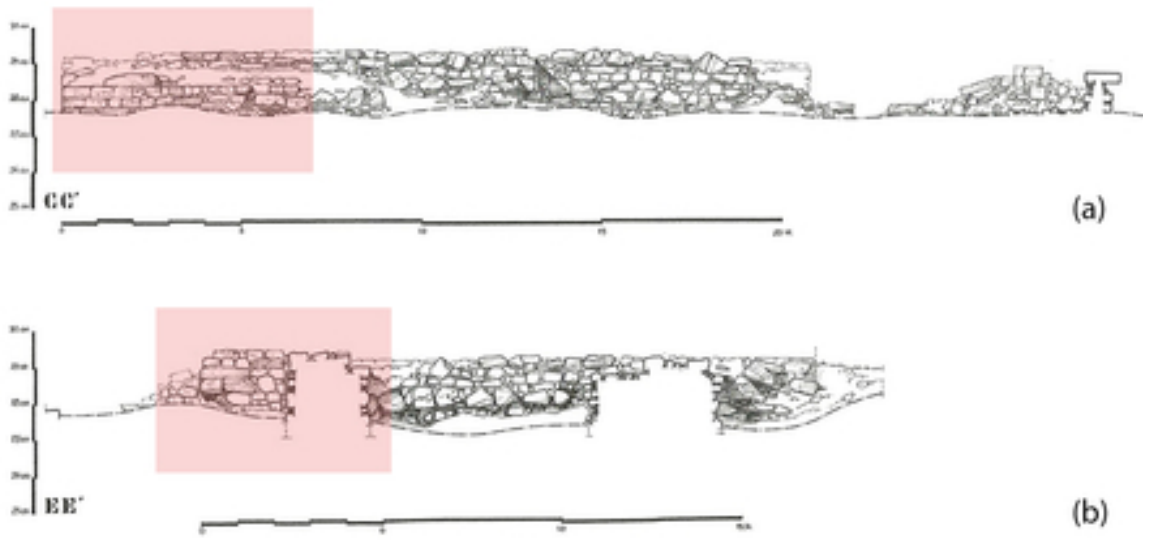

Section $\mathrm{EE}^{\prime}$ \& $\mathrm{FF}^{\prime}$ in the Temple of Dagan show the quality of the foundations' stones (Callot and Monchambert, 2011).

$74 \times 36 \mathrm{~mm}(150 \times 150 \mathrm{DPI})$ 


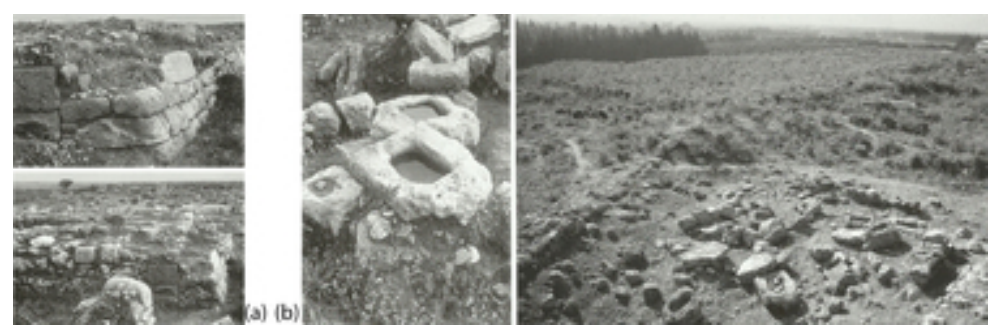

(a) Stone troughs found in the southeast courtyard of the Temple of Dagan. (b) The glaze added to the western wall of the Temple of Dagan.(Callot and Monchambert, 2011)

$63 \times 20 \mathrm{~mm}(150 \times 150 \mathrm{DPI})$ 


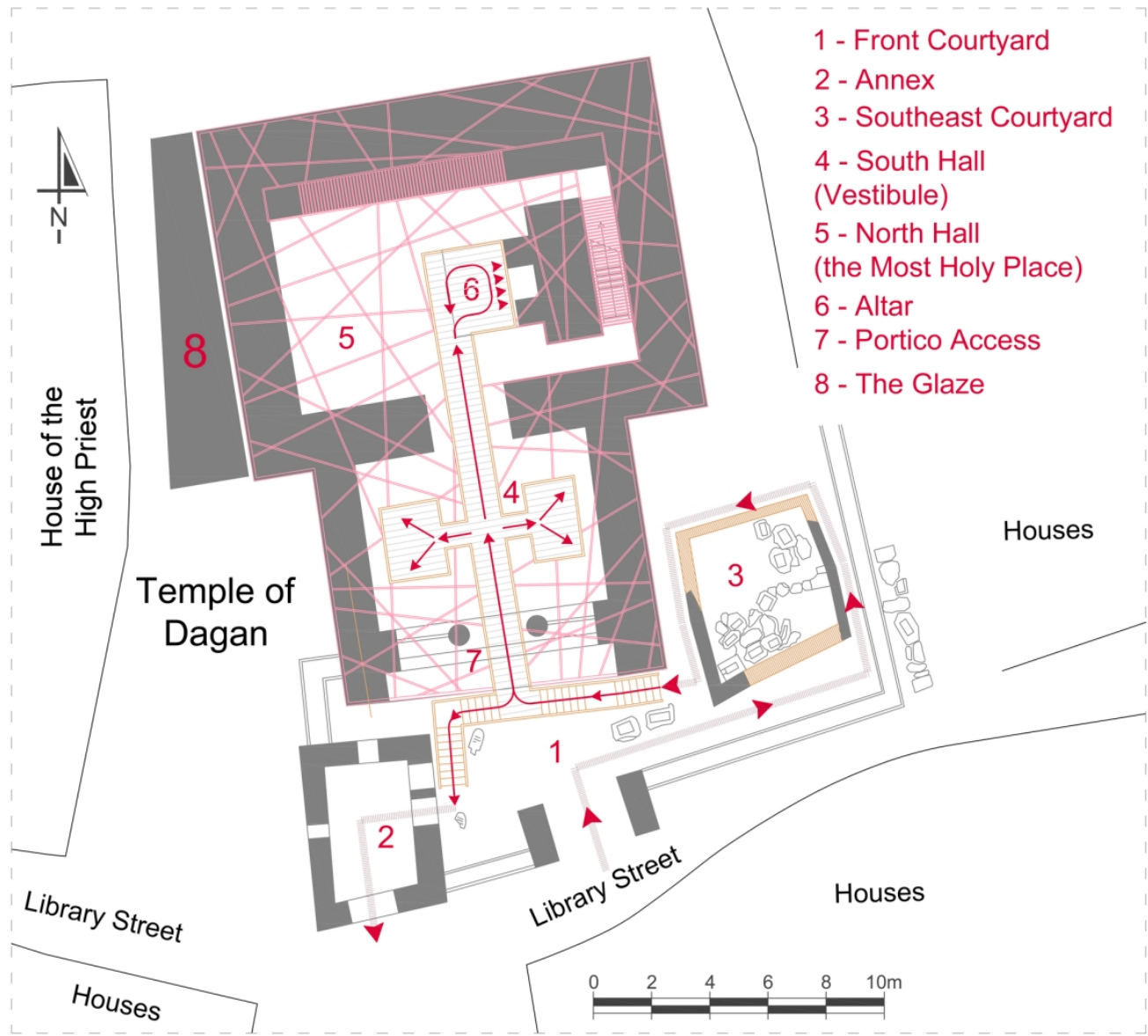

Detailed plan for the conservation proposal of the Temple of Dagan.

$318 \times 287 \mathrm{~mm}(150 \times 150 \mathrm{DPI})$ 

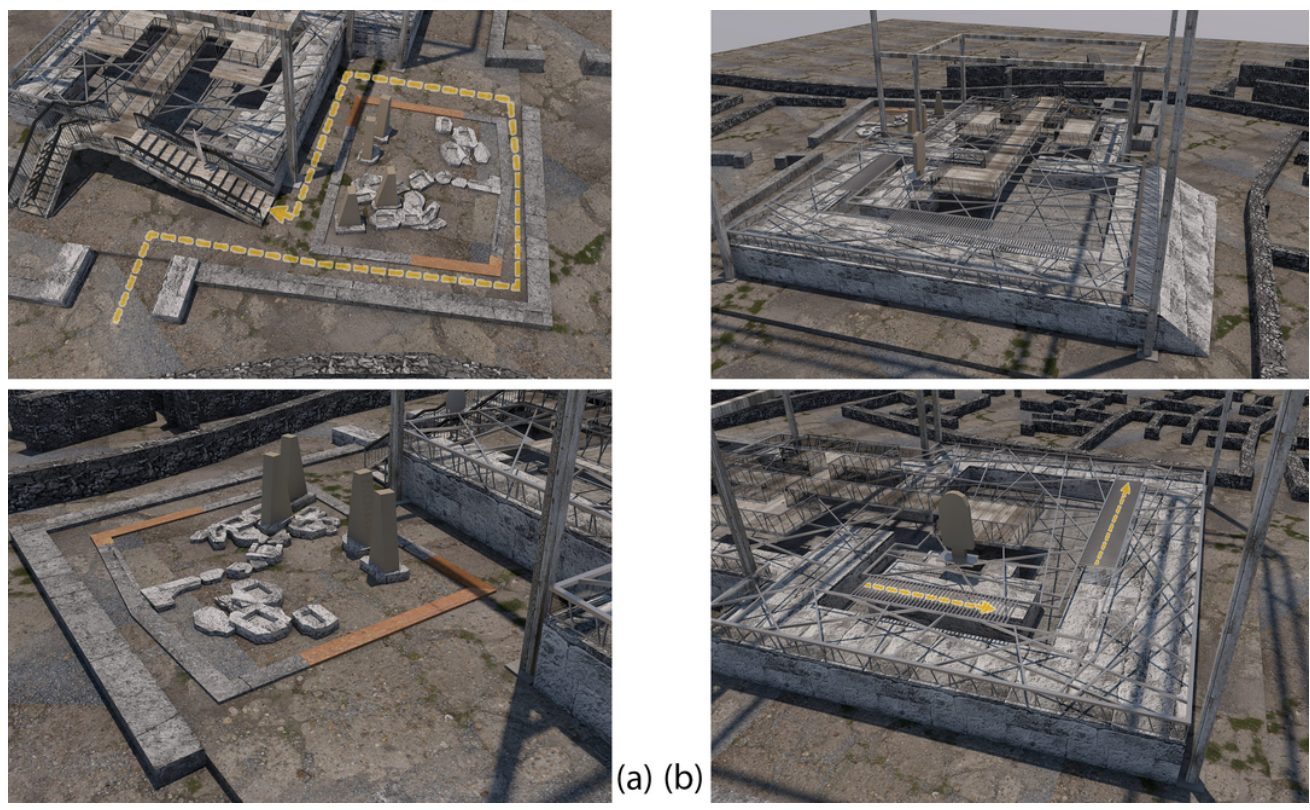

(a) (b)

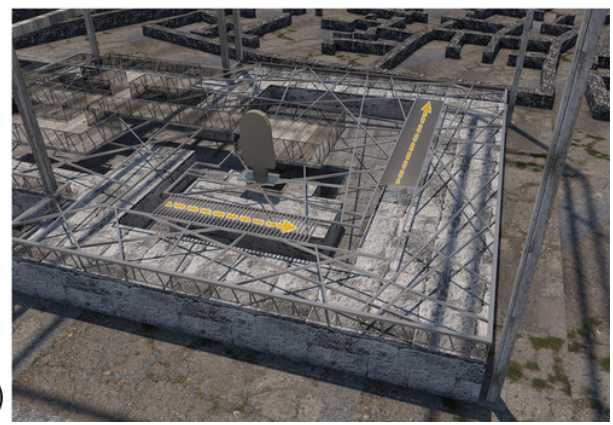

(a) Virtual conservation exploration for the southeast courtyard. (b) Virtual representation of the installed mesh on the temple's ruins, highlighting specific arrangements of the first phase.

$182 \times 111 \mathrm{~mm}(150 \times 150 \mathrm{DPI})$ 

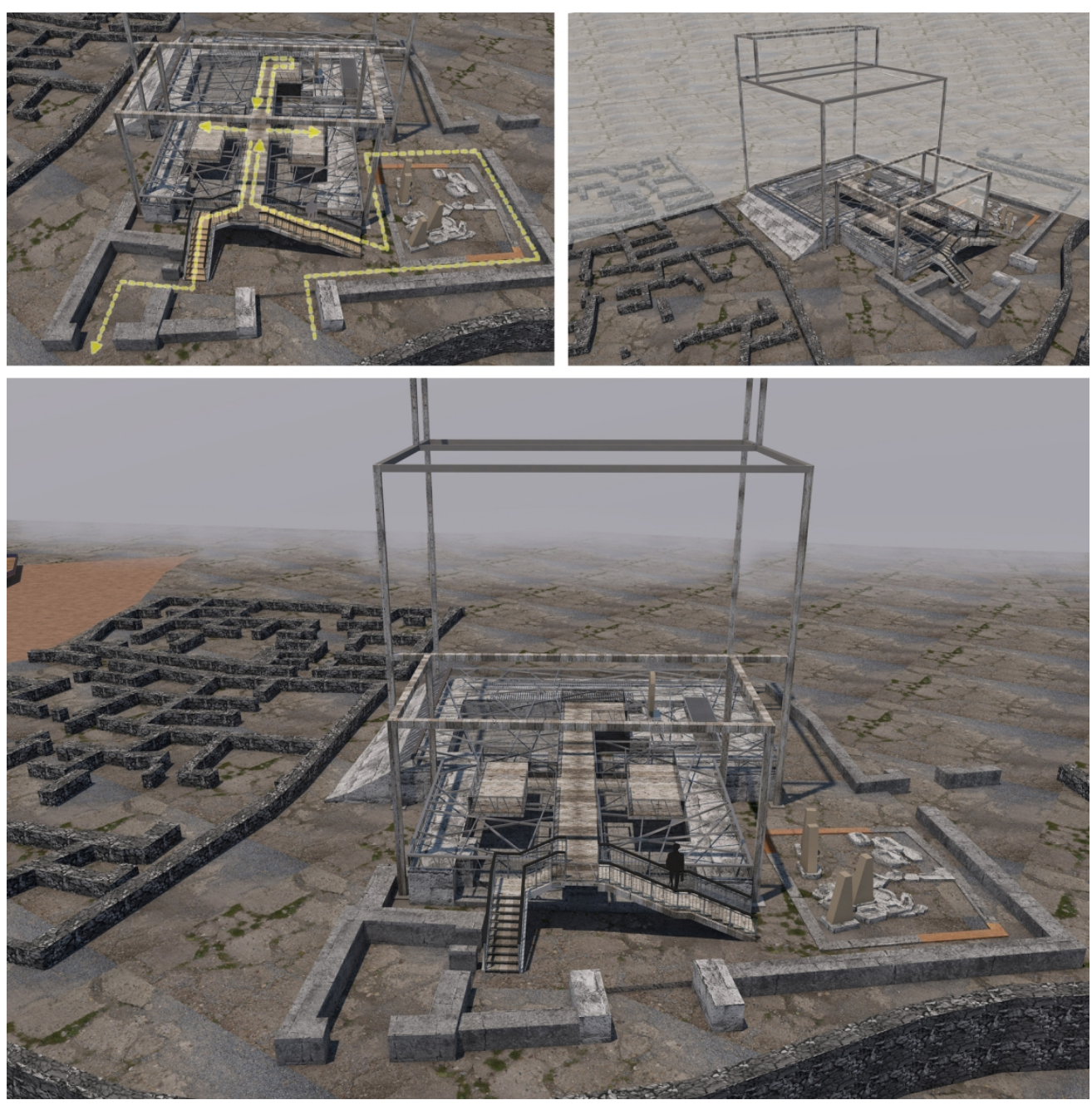

Virtual conservation exploration for the Temple of Dagan.

$301 \times 302 \mathrm{~mm}(150 \times 150 \mathrm{DPI})$ 